\title{
Inhibition of Protein Synthesis by Nitric Oxide Correlates with Cytostatic Activity: Nitric Oxide Induces Phosphorylation of Initiation Factor eIF-2 $\alpha$
}

\author{
Young-Myeong Kim, ${ }^{1,2,4}$ Kyonghee Son, ${ }^{3}$ Sun-Joo Hong, \\ Angela Green, ${ }^{1}$ Jane-Jane Chen, ${ }^{6}$ Edith Tzeng, \\ Christian Hierholzer, ${ }^{\prime}$ and Timothy R. Billiar ${ }^{1}$ \\ Departments of ${ }^{1}$ Surgery and ${ }^{2}$ Pharmacology, University of Pittsburgh, \\ Pittsburgh, Pennsylvania, U.S.A. \\ Department of ${ }^{3}$ Pharmaceutics, College of Pharmacy, Rutgers \\ University, Piscataway, New Jersey, U.S.A. \\ Departments of ${ }^{4}$ Molecular and Cellular Biochemistry, and \\ ${ }^{5}$ Biochemistry, Colleges of Medicine and Natural Sciences, \\ Kangwon National University, Kangwon-do, Chunchon, Korea \\ ${ }^{6}$ Harvard-MIT Division of Health Science and Technology, Cambridge, \\ Massachusetts, U.S.A. \\ Communicated by C. Nathan. Accepted January 26, 1998.
}

\begin{abstract}
Background: Nitric oxide (NO) is cytostatic for proliferating cells, inhibits microbial growth, and down-regulates the synthesis of specific proteins. Studies were undertaken to determine the mechanism by which NO inhibits total protein synthesis and whether the inhibition correlates with established cytostatic activities of NO. Materials and Methods: In in vitro experiments, various cell types were exposed to NO using either donors or expression of inducible NO synthase (iNOS). The capacity of NO to suppress total protein synthesis, measured by incorporation of ${ }^{35} \mathrm{~S}$-methionine into protein, was correlated with the capacity of NO to suppress cell proliferation, viral replication, or iNOS expression. Phosphorylation of eIF- $2 \alpha$ was examined as a possible mechanism for the suppressed protein synthesis by NO.

Results: Both NO donors and expression of the iNOS suppressed total protein synthesis in L929 cells and A2008 human ovarian tumor cells in parallel with decreased cell proliferation. Suppressed protein synthesis was also shown to correlate with decreased vaccinia virus proliferation in murine peritoneal macrophages in
\end{abstract}

an iNOS-dependent manner. Furthermore, iNOS expression in pancreatic islets or RAW264.7 cells almost completely inhibited total protein synthesis, suggesting that nonspecific inhibition of protein synthesis may be the mechanism by which NO inhibited the synthesis of specific proteins such as insulin or iNOS itself. This possibility was confirmed in RAW264.7 cells where the inhibition of total protein synthesis correlated with the decreased iNOS protein. The decrease in protein levels occurred without changes in iNOS mRNA levels, implicating an inhibition of translation. Mechanistic studies revealed that iNOS expression in RAW264.7 cells resulted in the phosphorylation of eIF- $2 \alpha$ and inhibition of the $80 \mathrm{~S}$ ribosomal complex formation.

Conclusions: These results suggest that NO suppresses protein synthesis by stimulating the phosphorylation of eIF-2 $\alpha$. Furthermore, our observations indicate that nonspecific inhibition of protein synthesis may be a generalized response of cells exposed to high levels of NO and that inhibition of protein synthesis may contribute to many of the described cytostatic actions of NO.

\section{Introduction}

Nitric oxide (NO) is generated from the amino acid L-arginine by three known NO synthase

Address correspondence and reprints to: Timothy R. Billiar, M.D., A1010 Presbyterian University Hospital, 200 Lothrop Street, Pittsburgh, PA 15213, U.S.A. Phone: 412-628-9862; Fax: 412-628-1033; E-mail: billiar@pittsurg.nb.upmc.edu
(NOS) isoforms. The quantities of NO produced by the high-output or inducible NOS (iNOS) can have profound influences on cell function and viability. The consequences of induced NO synthesis are dependent on the rate of NO formation, cell type, presence of other free radicals, and anti-oxidant status of the cell (1-3), among 
other factors. Induced NO is cytostatic or even cytotoxic to some cell types $(4,5)$ and has been shown to inhibit microbial growth (6). Mechanisms thought to be responsible for the cytostasis and cytotoxicity include direct inhibition of ribonucleotide reductase (7) as well as inhibition of key metabolic enzymes $(8,9)$. Under some conditions, direct toxicity is probably mediated by peroxynitrate, the reaction product of NO with superoxide (10). Exposure to levels of NO generated by iNOS also can induce a stress response marked by the up-regulation of heme oxygenase (11) and heat shock protein (hsp) 70 (12), which is thought to result from nitrogen oxide interaction with heme proteins $(11,13)$ or intracellular thiols (12). In hepatocytes, expression of iNOS is associated with a decrease in total protein synthesis (14-16). The mechanism of this inhibition remains to be established. It is also unknown if inhibition of protein synthesis is a common response of cells to levels of NO produced by iNOS. Furthermore, it is unclear how NO-induced suppression of protein synthesis relates to other cytostatic activities of NO, such as inhibition of cell proliferation (17), inhibition of the replication of intracellular pathogens $(18,19)$, or suppression of the synthesis of specific cellular proteins such as insulin (20) or even iNOS itself.

Protein synthesis may be regulated by initiation factor eIF-2 via phosphorylation of the $\alpha$ subunit. eIF-2 is required for the formation of the $43 \mathrm{~S}$ initiation complex followed by the assembly of the complete $80 \mathrm{~S}$ initiation complex in the presence of Met-tRNA $A_{i}^{\text {Met }}$. When eIF-2 $\alpha$ is phosphorylated, however, eIF-2 is inactive and protein synthesis is inhibited (21). Kinases responsible for the phosphorylation of eIF- $2 \alpha$ include the heme-regulated eIF- $2 \alpha$ protein kinase $(22,23)$, which is present in hematopoietic cells, and the RNA-dependent eIF- $2 \alpha$ protein kinases (PKR), which have a ubiquitous expression pattern (24). Mechanisms leading to the activation of PKR are only partially understood; however, PKR phosphorylation of eIF- $2 \alpha$ occurs in association with the inhibition of viral replication and tumor proliferation in cells exposed to interferon $(25,26)$, as well as in response to cellular stress (27). In the present study, we sought to determine whether inhibition of protein synthesis by NO is a generalized response that occurs in association with other cytostatic actions of NO. In addition, we tested whether the inhibition of protein synthesis by NO was associated with the increased phosphorylation of eIF- $2 \alpha$ and inhibition of $80 \mathrm{~S}$ complex formation.

\section{Materials and Methods}

\section{Materials}

Williams media E, penicillin, streptomycin, L-glutamine, and Hepes were purchased from Gibco (Grand Island, NY). Insulin was purchased from Eli Lilly Co. and calf serum was obtained from Hyclone Laboratories (Logan, UT). The murine macrophage anti-iNOS monoclonal antibody was obtained from Transduction Laboratories (Lexington, KY). Monoclonal anti-eIF-2 $\alpha$ was provided by Dr. E. C. Henshaw. S-nitroso$\mathrm{N}$-acetylpenicillamine (SNAP) was synthesized every 2 months as described previously (11), stored frozen as a solid aliquot in the dark, and checked for stoichiometric $S$-nitrosothiol content by the method of Saville (28). $\mathrm{N}^{\mathrm{G}}$-monomethylL-arginine (NMA) was purchased from Cyclopss (Salt Lake City, UT). Red blood cells were isolated as previously described (6). Adenoviral vectors carrying either the cDNA for human iNOS or $\beta$-galactosidase (lacZ) were prepared and tested as previously described (29). All other chemicals and proteins were purchased from Sigma, (St. Louis, MO) unless indicated otherwise.

\section{Isolation of Islets and Peritoneal Macrophages, and Cell Culture}

All animal protocols were approved by the University of Pittsburgh Animal Care and Use Committee. Primary cultures of peritoneal macrophages or pancreatic islets were prepared from 6-week-old iNOS knock-out (iNOS -l-) or wild-type (iNOS $+l+$ ) mice (obtained from C. Nathan and J. Mudget) as previously described $(5,30)$. Macrophages were cultured in Williams media E supplemented with $2 \mathrm{mM}$ L-glutamine, $100 \mathrm{U} / \mathrm{ml}$ penicillin, $100 \mu \mathrm{g} / \mathrm{ml}$ streptomycin, and $10 \%$ low endotoxin calf serum in $5 \% \mathrm{CO}_{2}-$ $95 \%$ air at $37^{\circ} \mathrm{C}$. The murine macrophage cell line RAW264.7 was also maintained and cultured in supplemented Williams media E. Macrophages were stimulated with LPS $(1 \mu \mathrm{g} / \mathrm{ml})$ and IFN- $\gamma(100 \mathrm{U} / \mathrm{ml})$. Pancreatic islets were cultured with RPMI 1640 (Gibco BRL) containing $11.1 \mathrm{mmol} / \mathrm{l}$ glucose, $50 \mathrm{U} / \mathrm{ml}$ penicillin, 50 $\mu \mathrm{g} / \mathrm{ml}$ streptomycin, and $10 \%$ heat-inactivated fetal bovine serum (FBS) in $5 \% \mathrm{CO}_{2}-95 \%$ air at $37^{\circ} \mathrm{C}$. Islets were transduced with adenoviral iNOS (AdiNOS) or adenovirus lacZ (AdlacZ) at a multiplicity of infection (MOI) of 200 to 1 for 4 $\mathrm{hr}$. The murine fibroblast cell line L929 and the human breast carcinoma cell line A2008 were 
cultured with supplemented Dulbecco's modified Eagle's medium (DMEN) containing 10\% FBS.

Isolation of a Stable Transfectant Expressing IFN- $\gamma$ and Coculture with RAW264.7 cells

Human breast carcinoma A2008 cells were transfected with pCMV-IFN- $\gamma$ as previously described (31). Transfectants were selected by G418. The cells were precultured in the bottom of a 12-well transwell plate (Corning, Cambridge, MA) until $60 \%$ to $70 \%$ confluent, and then co-cultured with RAW264.7 cells $\left(5 \times 10^{6}\right.$ cells $)$ in the presence and absence of $2 \mathrm{mM}$ NMA. Cell proliferation and protein synthesis were measured as described below.

\section{Virus Growth and Titration}

Vaccinia virus was propagated in BSC-40 cells and purified by sucrose sedimentation. Virus titer was determined by serial dilution and plaque assays in BSC-40 cells (32). Virus infectivity in cell culture was determined as described elsewhere (18). Peritoneal macrophages $\left(2.5 \times 10^{5}\right.$ cells/well) were stimulated with IFN- $\gamma$ (100 $\mathrm{U} / \mathrm{ml}$ ) plus LPS $(1 \mu \mathrm{g} / \mathrm{ml})$ for $8 \mathrm{hr}$ before infection, and virus was added at 1 plaque-forming unit (PFU)/well. After $1 \mathrm{hr}$ incubation at $37^{\circ} \mathrm{C}$, cells were washed three times with phosphatebuffer saline (PBS) and repleted with complete media. After $18 \mathrm{hr}$ incubation at $37^{\circ} \mathrm{C}$, cells were scraped into culture media, lysed by three freezethaw cycles and sonication, and serially diluted. Virus yields were determined by plaque assays in BSC-40 cells.

\section{Determination of Protein Synthesis}

Total protein synthesis was determined by labeling with ${ }^{35} \mathrm{~S}$-methionine $(50 \mu \mathrm{Ci} / \mathrm{ml})$ for 2 to 6 hr. The cells were washed three times with PBS and lysed in $40 \mathrm{mM}$ Tris- $\mathrm{HCl}, \mathrm{pH} 7.5$, by four freeze-thaw cycles. The incorporation of labeled methionine into proteins was analyzed by SDSPAGE or scintillation counting after protein precipitation with ice-cold trichloroacetic acid.

\section{Cell Proliferation}

L929 or A2008 cells were cultured in 12-well plates until $\sim 70 \%$ confluent. Cells were pretreated with SNAP solution or cocultured with RAW264.7 for $8 \mathrm{hr}$ and labeled with $5 \mu \mathrm{Ci} / \mathrm{ml}$ ${ }^{3} \mathrm{H}$-thymidine for $18 \mathrm{hr}$. The plates were treated with ice-cold $10 \%$ trichloroacetic acid $(0.5 \mathrm{ml} /$ well) and kept at $4^{\circ} \mathrm{C}$ overnight. The plates were washed three times with distilled water and dried at room temperature. Cells were collected with $0.5 \mathrm{ml} /$ well of $0.33 \mathrm{mM} \mathrm{NaOH}$ and $300 \mu \mathrm{l}$ of solution was transferred into a scintillation vial containing scintillation fluid. ${ }^{3} \mathrm{H}$-thymidine incorporation into DNA was measured using a scintillation counter.

\section{Analysis of eIF-2 $\alpha$ Phosphorylation}

RAW264.7 cell pellets $\left(1 \times 10^{6}\right.$ cells $)$ were dissolved in sample buffer $(240 \mu \mathrm{l})$ containing $3.5 \%$ ampholine (4 parts $\mathrm{pH} 4-8$ and 1 part $\mathrm{pH} 3.5-$ $10), 1 \% \beta$-mercaptoethanol, $0.2 \%$ Tween 20 , $9.5 \mathrm{M}$ urea, $20 \mathrm{mM}$ sodium fluoride, and $5 \%$ Chaps. The mixture was subjected to vertical slab gel isoelectric focusing (VIEF) and immunoblot analysis with monoclonal anti-eIF- $2 \alpha$ antibody as previously described (33).

\section{Ribosome Profiles in Sucrose Gradients}

RAW264.7 cells were rapidly isolated in ice-cold PBS containing $100 \mu \mathrm{g} / \mathrm{ml}$ cycloheximide. After centrifugation at maximum speed in a microcentrifuge for $10 \mathrm{sec}$, the pellets were resuspended in hypotonic swelling buffer $(40 \mathrm{mM}$ Tris- $\mathrm{HCl}[\mathrm{pH}$ 7.4], $20 \mathrm{mM} \mathrm{KCl}, 3 \mathrm{mM} \mathrm{MgCl}, 20 \mathrm{mM}$ sodium fluoride, and $150 \mathrm{mM}$ sucrose) and kept on ice for an additional $10 \mathrm{~min}$. The cells were lysed in $1 \%$ Triton X-100 and $1 \%$ deoxycholate (final concentration) followed by vigorous vortexing. The lysate was centrifuged for $1 \mathrm{~min}$ at maximum speed in a microcentrifuge and the supernatants $(240 \mu \mathrm{l})$ were layered onto a linear 15$40 \%$ sucrose gradient containing $25 \mathrm{mM}$ Tris $\mathrm{HCl}$ (pH 7.4), $80 \mathrm{mM} \mathrm{KCl}, 4 \mathrm{mM} \mathrm{MgCl}{ }_{2}$, and $20 \mathrm{mM}$ sodium fluoride. Following centrifugation at $35,000 \mathrm{rpm}$ for $4 \mathrm{hr}$ in a Beckman SW-41 rotor, ribosomal profiles were monitored by continuously measuring absorbance at $280 \mathrm{~nm}$.

\section{Other Treatments and Assays}

Nitrite was measured by Griess reagents and total nitrite + nitrate was measured by high-performance liquid chromatography (HPLC) based on the Griess reaction, in which the nitrate is converted to nitrite using copper-coated cadmium (5). Protein was determined by protein assay kit (P5656, Sigma). NOS activity was measured as previously described (34). 
A

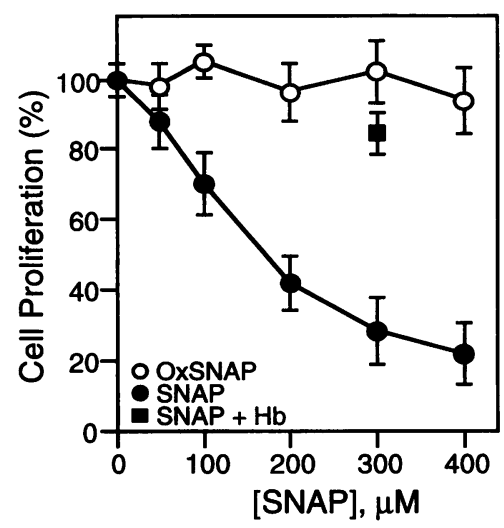

FIG. 1. Exogenous NO inhibits cell proliferation and protein biosynthesis. (A) Cell proliferation. L929 cells were cultured in 12-well plates until $\sim 70 \%$ confluence and cells were treated with either SNAP or oxidized SNAP solutions containing 5 $\mu \mathrm{Ci} / \mathrm{ml}^{3} \mathrm{H}$-thymidine for $18 \mathrm{hr}$. Some cells were treated with the NO scavenger oxyhemoglobin at $480 \mu \mathrm{M}$. ${ }^{3} \mathrm{H}$-thymidine incorporation into DNA was measured using a scintillation counter. (B) Protein

\section{Results}

NO-Induced Inhibition of Protein Synthesis Correlates with Inhibition of Cell Proliferation

NO has been shown to be cytostatic for a number of cell types $(4,17)$. To determine whether the cytostatic activity of NO was associated with a suppression of total protein synthesis, L929 cells were exposed to the NO donor SNAP in concentrations ranging from 0 to $400 \mu \mathrm{M}$. No toxicity, as measured by LDH release or DNA fragmentation, was detected at these SNAP concentrations (data not shown). A concentration-dependent inhibition of cell proliferation was measured at $18 \mathrm{hr}$ following SNAP exposure based on assessment of thymidine incorporation (Fig. 1A) and confirmed by crystal violet and trypan blue staining of these cells (data not shown). The suppression of proliferation by SNAP was associated with a parallel decrease in total protein synthesis measured by ${ }^{35} \mathrm{~S}$-methionine incorporation (Fig. 1B). SNAP, which had been preincubated in solution to release all of the NO prior to the addition to the cells, had no effect. Both the anti-proliferative effects as well as the suppression of protein synthesis by SNAP were reversed by the addition of the NO scavenger oxyhemoglobin (Fig. 1A,B).

To determine whether iNOS expression also suppressed tumor cell protein synthesis in conjunction with decreased cell proliferation, hu-
B

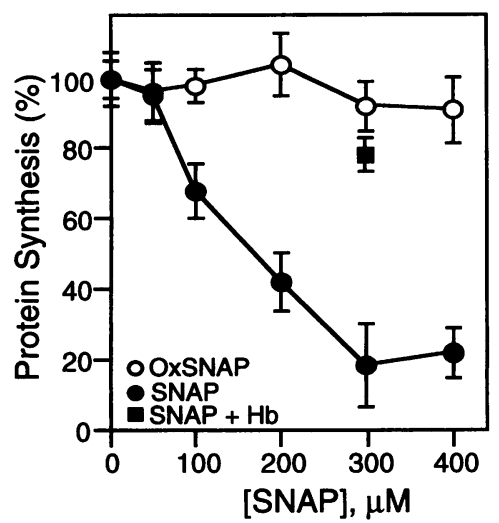

synthesis. L929 cells were incubated with media containing SNAP or oxidized SNAP for $4 \mathrm{hr}$ and then ${ }^{35} \mathrm{~S}$-methionine was directly added into the culture media. After a $6 \mathrm{hr}$ incubation, ${ }^{35} \mathrm{~S}$-methionine incorporation into protein was measured after precipitation with TCA using a scintillation counter. All data are expressed as mean \pm SD of more than two independent experiments, each performed in triplicate.

man ovarian A2008 tumor cells, stably transfected to overexpress either IFN- $\gamma$ or lacZ, were co-incubated with the murine macrophage cell line RAW264.7. The IFN- $\gamma$-producing A2008 cells stimulated NO production by the RAW264.7 cells as measured by nitrite release (31) into the culture media. NO production was almost completely inhibited by the addition of NMA (Fig. 2A). Both cell proliferation and total protein synthesis in the co-cultures were suppressed by about $30 \%$ in an NO-dependent manner (Fig. 2B, C). Incubation of the A2008 cells with SNAP also suppressed proliferation and protein synthesis in a concentration-dependent manner (data not shown). These data demonstrate that the cytostatic effect of NO on tumor cells is associated with concomitant depression in total protein synthesis.

NO-Induced Inhibition of Protein Synthesis Is Associated with Decreased Viral Proliferation

Anti-viral activity in many cell types is attributed to an inhibition of protein synthesis thought to result from the phosphorylation of eIF- $2 \alpha$ by PKR kinase (35). Since NO has been shown to inhibit viral replication in macrophages $(18,19)$, experiments were carried out to determine whether iNOS-dependent inhibition of vaccinia virus replication in murine macrophages was as- 
A

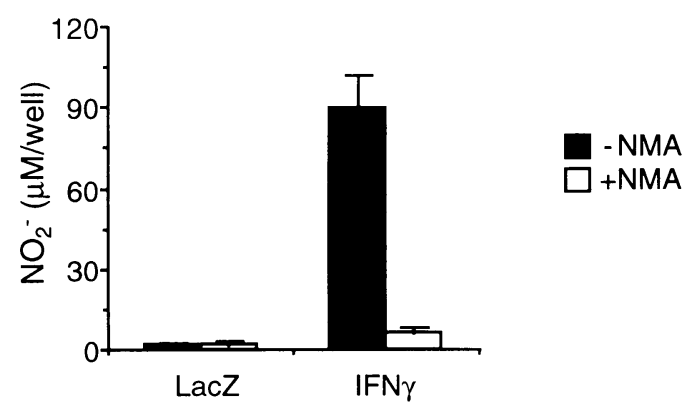

\section{B}

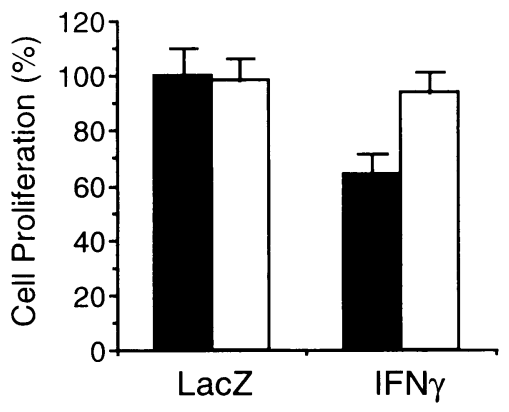

FIG. 2. iNOS expression inhibits cell proliferation and protein biosynthesis. (A) NO production. Stable A2008 transfectants with pCMV-IFN- $\gamma$ were co-cultured with RAW264.7 in the presence or absence of NMA for $24 \mathrm{hr}$. Nitrite levels in the culture media were determined by the Griess reaction. (B) Cell proliferation. Co-cultured cells were labeled with ${ }^{3} \mathrm{H}$-thymidine for $18 \mathrm{hr}$ for determination of

sociated with an NO-dependent suppression of total protein synthesis. Peritoneal macrophages were isolated from iNOS knockout (KO, iNOS $-1-)$ mice as well as their counterpart wild-type (WT, iNOS $+/+$ ) mice. These cells were exposed to LPS + IFN- $\gamma$ and, as expected, only the peritoneal macrophages from the WT mice produced $\mathrm{NO}$ as measured by the accumulation of nitrite in the culture media (Fig. 3A). Exposure to LPS + IFN- $\gamma$ suppressed both total protein synthesis and viral replication in the macrophages from the WT mice (Fig. 3B). In contrast, macrophages from KO animals exhibited no decrease in protein synthesis and significantly greater viral replication. NMA inhibited $\mathrm{NO}_{2}^{-}$accumulation and reversed the effects of LPS + IFN- $\gamma$ on protein synthesis and viral replication of WT macrophages. These data show that peritoneal macrophage protein synthesis is suppressed by iNOS expression, and this is associated with depressed viral replication.

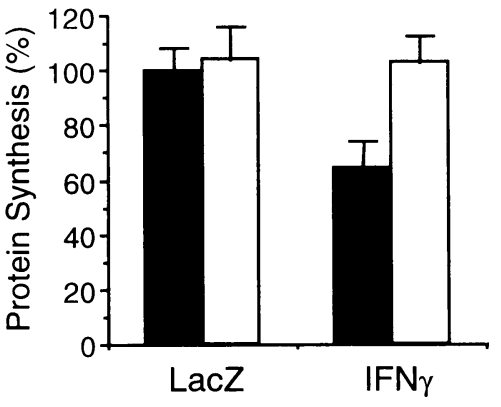

proliferation rates. (C) Protein synthesis. After coculture for $16 \mathrm{hr}$, cells were incubated with ${ }^{35} \mathrm{~S}$-methionine for $4 \mathrm{hr}$. Incorporation of ${ }^{35} \mathrm{~S}$-methionine into protein was measured using a scintillation counter after TCA precipitation. All data are expressed as mean \pm SD of three independent experiments, each performed in duplicate.

iNOS Expression in Pancreatic Islets Suppresses Total Protein Synthesis

iNOS expression suppresses glucose-stimulated insulin secretion in rat and human pancreatic islets $(20,36)$. It is unknown whether iNOS expression also suppresses total protein synthesis in pancreatic islets. We treated islets isolated from either WT or iNOS KO mice with $20 \mathrm{U} / \mathrm{ml}$ of IL- $1 \beta$ and measured NO production and protein synthesis. IL- $1 \beta$ elicited NO production (approximately 4.5 pmole of $\mathrm{NO}_{2}^{-} /$islet $/ 24 \mathrm{hr}$ ) in WT islets, but not in islets isolated from $\mathrm{KO}$ mice (Fig. 4A). Under the same experimental conditions, IL-1 $\beta$ inhibited total protein synthesis in islets from WT animals, but not $\mathrm{KO}$ islets (Fig. 4B). The suppression of protein synthesis was completely reversed in the islets from WT mice by the addition of NMA (Fig. 4B). To determine whether iNOS expression independent of cytokine addition would also inhibit protein 


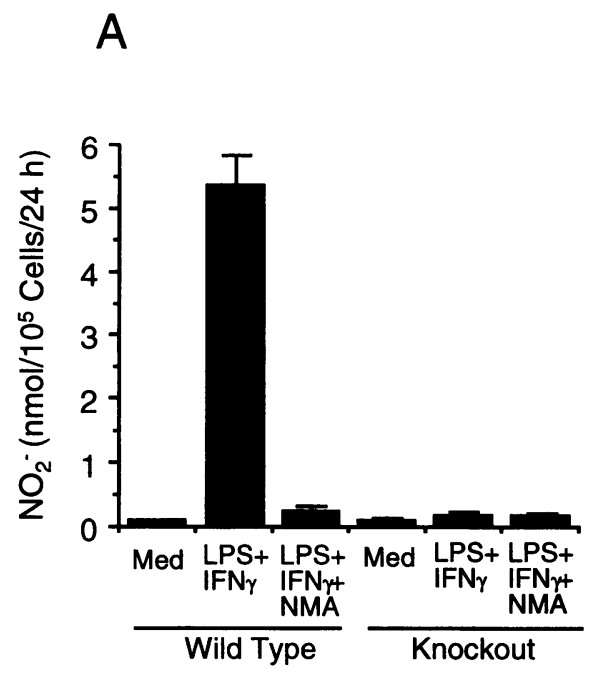

FIG. 3. NO inhibits viral replication and protein biosynthesis in primary mouse peritoneal macrophages. (A) Peritoneal macrophages from iNOS knock-out and wild-type mice were stimulated with LPS + IFN- $\gamma$ for $24 \mathrm{hr}$ and $\mathrm{NO}_{2}^{-}$levels determined in the culture media by the Griess reaction. (B) After $8 \mathrm{hr}$ stimulation with LPS + IFN- $\gamma \pm$ NMA, peritoneal macrophages were infected with

synthesis, islets from both WT and KO mice were transduced with the human iNOS CDNA using an adenoviral vector. As shown in Figure 4C, overexpression of iNOS, but not lacZ, suppressed total protein synthesis in islets from both WT and KO mice. This effect was reversed by the addition of NMA. These data demonstrate that IL- $1 \beta$ suppresses total protein synthesis in cultured islets through an iNOS-dependent mechanism.

\section{Inhibition of Total Protein Synthesis and iNOS} Translation in RAW264.7 Cells by NO

If NO production efficiently suppresses total protein synthesis, then induced NO production should result in decreased iNOS protein levels. RAW264.7 cells exposed to LPS + IFN- $\gamma$ exhibited increased NO production in a time-dependent manner with the accumulation of nitrite in the media apparent after $3 \mathrm{hr}$ and peaking at 12 hr (Fig. 5A). Red blood cells (RBC) efficiently inactivate NO in cell culture (37); the addition of RBC to stimulated RAW264.7 cells resulted in a 3 -fold increase in nitrite + nitrate accumulation in the media with no plateau apparent after 12 hr. iNOS enzyme activity was significantly increased in lysates of RAW264.7 cells $12 \mathrm{hr}$ after exposure to LPS + IFN- $\gamma$. Incubation of the stim-

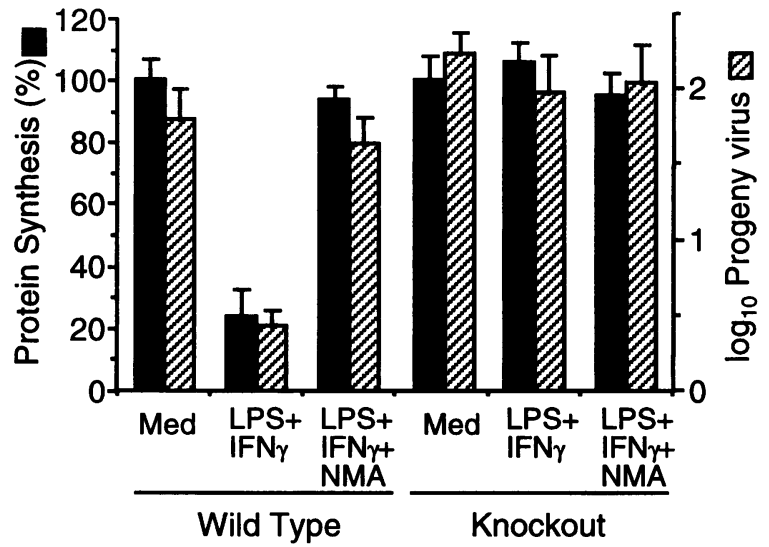

vaccinia virus. After an $18 \mathrm{hr}$ incubation, viral proliferation was measured by plaque-forming assay. Protein synthesis was assessed by measuring ${ }^{35} \mathrm{~S}$-methionine incorporation into proteins after a $4 \mathrm{hr}$ labeling interval. All data are expressed as mean \pm SD of two independent experiments, each performed in triplicate.

ulated cells with NO scavengers, including RBC, lysates from $\mathrm{RBC}$, or purified hemoglobin, resulted in increases in intracellular iNOS activity as well as increased nitrite + nitrate release by the cultured cells. RBC ghosts, which have no scavenging activity, did not share this effect (Fig. 5B). Thus NO inhibited expression and/or activity of iNOS.

To determine whether NO decreased iNOS protein levels, Western blot analysis was performed on lysates from LPS + IFN- $\gamma$-treated RAW264.7 cells cultured with or without NMA. iNOS protein levels were first detectable at $4 \mathrm{hr}$ and became greater in the NMA-treated cells at time points of $8 \mathrm{hr}$ or longer. The NO-dependent suppression in iNOS protein levels was associated with an almost complete inhibition of total protein synthesis as measured by the detection of newly synthesized radiolabeled proteins on SDSPAGE (Fig. 5C). To determine if the decrease in iNOS protein was associated with a change in steady-state mRNA levels, Northern blot analysis was performed (Fig. 5D). Stimulation of RAW264.7 cells with LPS + IFN- $\gamma$ resulted in the appearance of iNOS message, which was not influenced by the addition of NMA or RBC; however, both treatments resulted in a significant increase in iNOS protein as measured by Western 

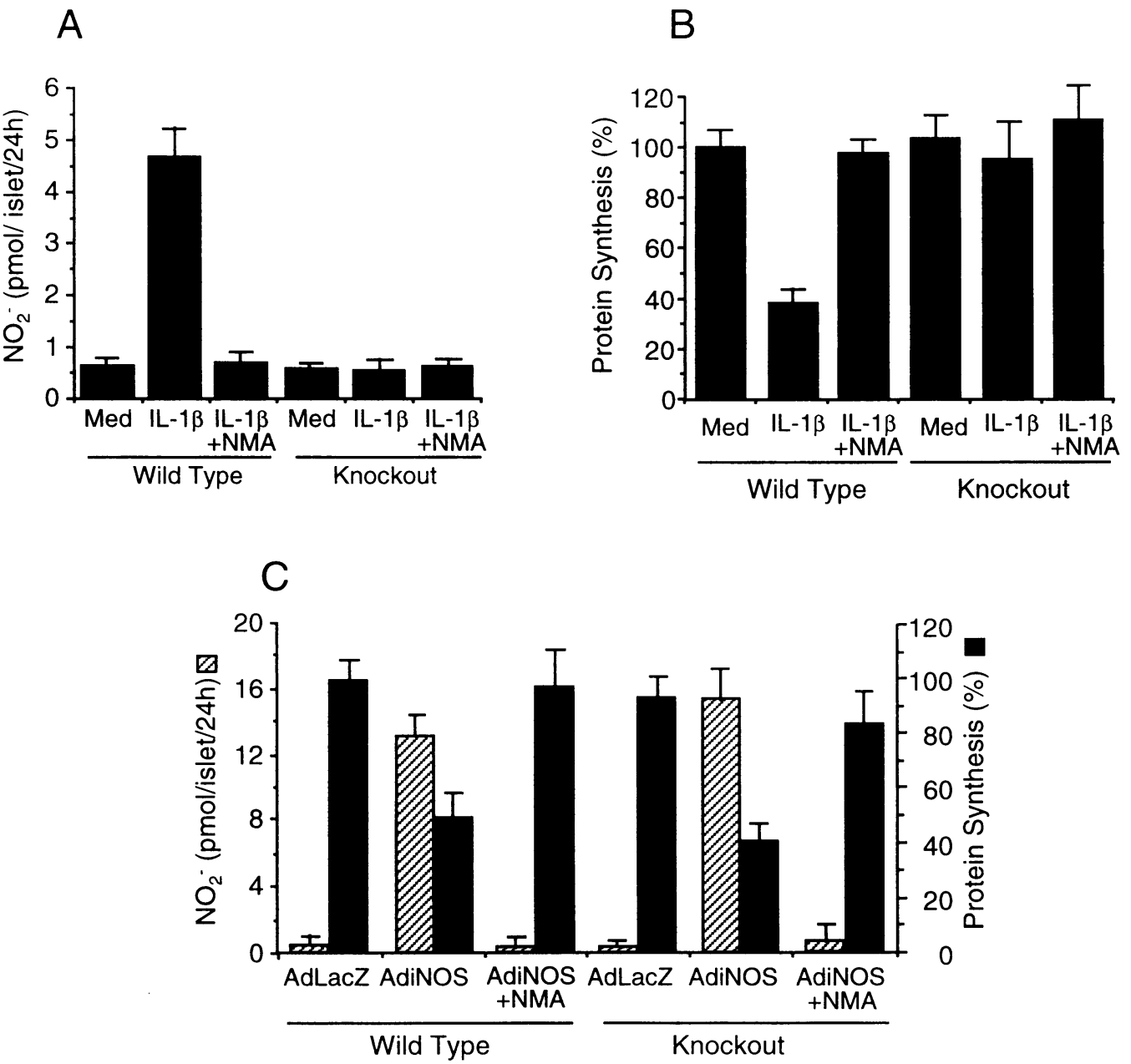

FIG. 4. iNOS expression inhibits protein biosynthesis in primary mouse islets in culture. (A) Pancreatic islets isolated from iNOS knock-out and wild-type mice were stimulated with $40 \mathrm{U} / \mathrm{ml}$ IL- $1 \beta$ in the presence or absence of $2 \mathrm{mM}$ NMA for $24 \mathrm{hr}$. NO production was measured by the Griess reaction. (B) Islets were stimulated with IL- $1 \beta$ for 14 $\mathrm{hr}$ and then incubated with ${ }^{35} \mathrm{~S}$-methionine for $4 \mathrm{hr}$.

${ }^{35} \mathrm{~S}$-methionine incorporation into proteins was

blot analysis. These data show that RAW264.7 cells are subject to inhibition of total protein synthesis by iNOS expression and this includes a significant reduction in iNOS protein levels.

\section{NO Exposure Is Associated with Phosphorylation of eIF- $2 \alpha$ and Inhibition of the 80 S Ribosomal Complex Formation}

Phosphorylation of initiation factor eIF- $2 \alpha$ suppresses total protein synthesis (38). To determine whether exposure to NO resulted in the phosphorylation of eIF- $2 \alpha$, lysates from RAW264.7 measured by scintillation counting after TCA precipitation. (C) Islets were transfected with adenoviral vector carrying LacZ (AdlacZ) or iNOS (AdiNOS) for $4 \mathrm{hr}$, washed twice with media, and cultured with fresh media. Nitrite was measured at $18 \mathrm{hr}$ and ${ }^{35} \mathrm{~S}$ methionine incorporation in new proteins was determined after a 4-hr labeling interval. All data are expressed as mean \pm SD of two independent experiments, each performed in triplicate.

cells were obtained following exposure to LPS + IFN- $\gamma$ with or without NMA for $14 \mathrm{hr}$, and proteins were separated by isoelectric focusing. Phosphorylation of eIF- $2 \alpha$ was measured by Western blot analysis (Fig. 6A). Following LPS + IFN- $\gamma$ treatment, approximately $95 \%$ of the eIF-2 $\alpha$ was phosphorylated (lower band), and this phosphorylation was reversed if the cells were incubated with LPS + IFN- $\gamma$ in the presence of NMA or RBC. eIF-2 is required for the initiation of protein synthesis by promoting the formation of the $43 \mathrm{~S}$ preinitiation complex, and therefore, the $80 \mathrm{~S}$ ribosomal complex (39). We 


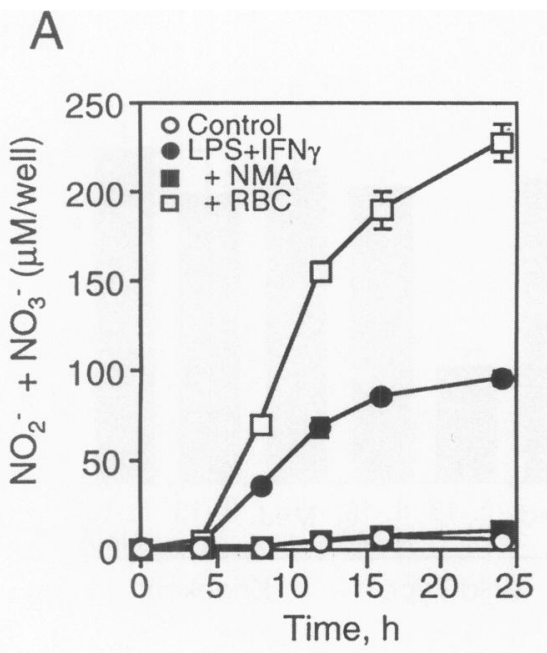

C

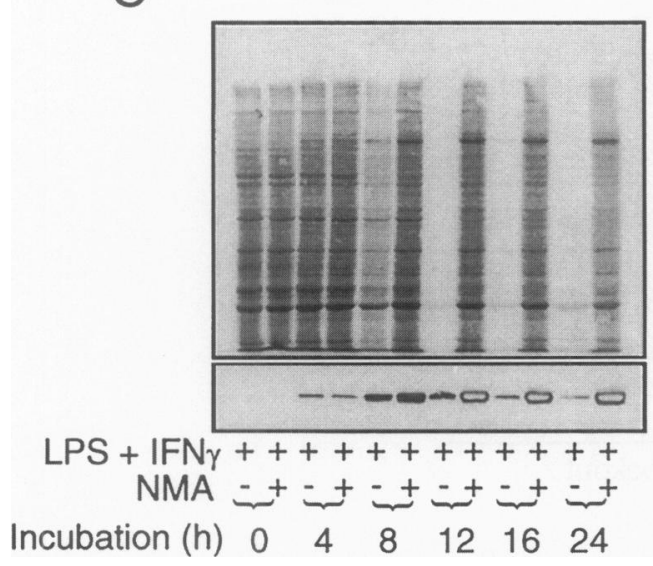

FIG. 5. NO inhibits iNOS translation in RAW264.7 macrophages. (A) RAW264.7 cells were stimulated with LPS $(1 \mu \mathrm{g} / \mathrm{ml})$ and IFN- $\gamma(100$ units $/ \mathrm{ml}$ ) in the presence or absence of 2 mM NMA or purified red blood cells ( $400 \mu \mathrm{M}$ of hemoglobin). Nitrite + nitrate was measured in culture media as described in Materials and Methods. Data are expressed as mean $\pm \mathrm{SD} ; n \geq 4$. (B) Nitrite + nitrate accumulation in the culture media (solid bars) and NOS activity (hatched bars) were determined in RAW264.7 cells stimulated with LPS + IFN- $\gamma$ for 12 hr. Cells were collected and lysed in Tris- $\mathrm{HCl}, \mathrm{pH}$ 7.4, by three cycles of freezing and thawing. NOS activity was determined by measuring nitrite and nitrate from L-arginine in the presence of NADPH,

examined the effect of NO synthesis on ribosomal complex formation by sucrose density gradient analysis (Fig. 6B). Lysates from RAW264.7 cells incubated with LPS + IFN- $\gamma$ for $14 \mathrm{hr}$ exhibited a marked decrease in $80 \mathrm{~S}$ complex formation and an increase in appearance of the $60 \mathrm{~S}$
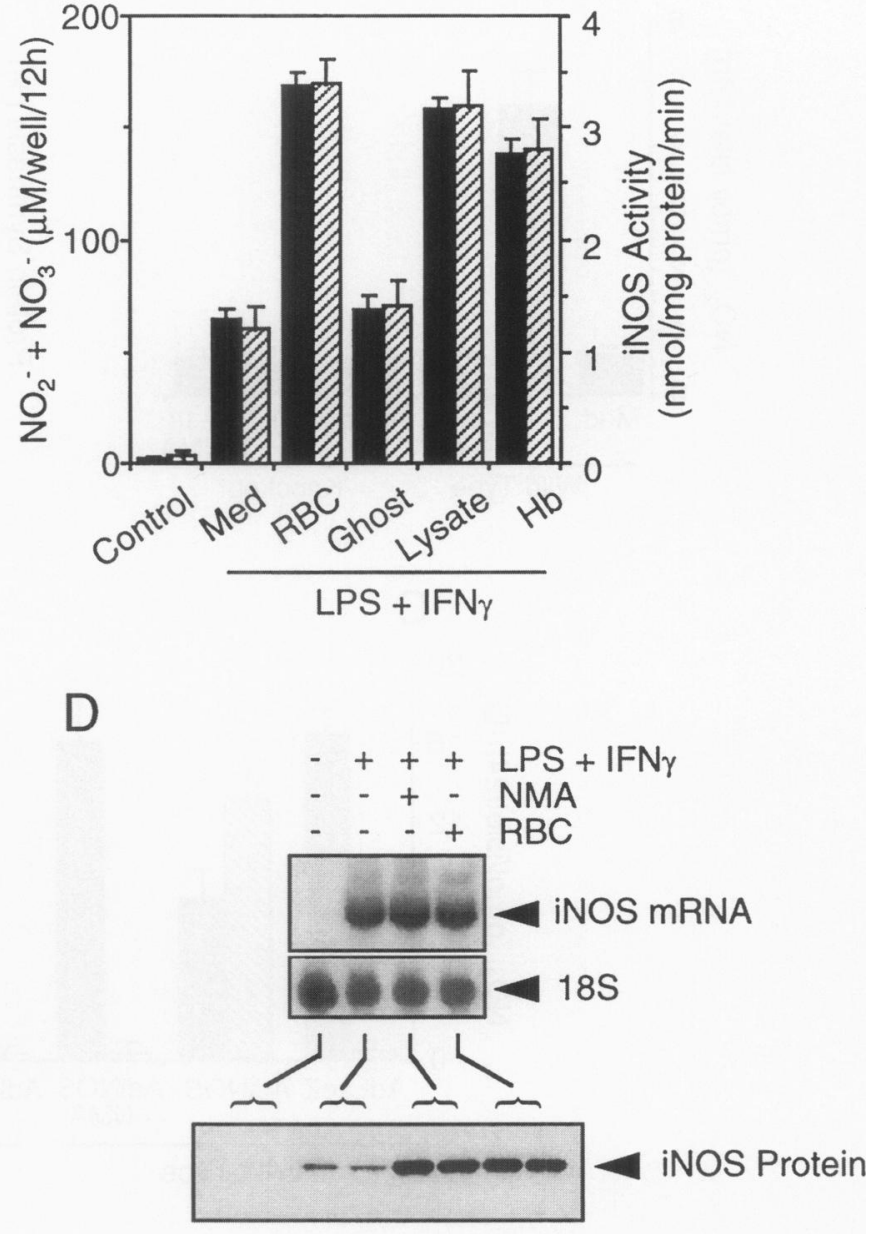

FAD, FMN, and $\mathrm{BH}_{4}$ (see Materials and Methods). Data are expressed as mean $\pm \mathrm{SD} ; n \geq 3$. (C) Protein synthesis was measured in RAW264.7 cells stimulated with LPS + IFN- $\gamma$. At the indicated time points, cells were labeled with ${ }^{35} \mathrm{~S}$-methionine for 2 $\mathrm{hr}$ and the labeled proteins separated on SDS-PAGE. Protein synthesis levels (upper panel) and iNOS protein (lower panel) were analyzed by exposing the membrane to X-ray film and Western blot, respectively. The ring-like iNOS protein bands detected by Western blot after the 12-hr incubation with NMA are due to the rapid exhaustion of the peroxidase substrate by the high levels of iNOS protein. (D) Abundance of iNOS mRNA and protein were analyzed by Northern and Western blot, respectively.

and $43 \mathrm{~S}$ subunits. If the cells were incubated in the presence of the NOS inhibitor NMA, levels of free $43 \mathrm{~S}$ and $60 \mathrm{~S}$ as well as $80 \mathrm{~S}$ ribosomal complex were reverted to the levels in untreated cells. These data indicate that NO synthesis is accompanied by the phosphorylation of eIF- $2 \alpha$ 

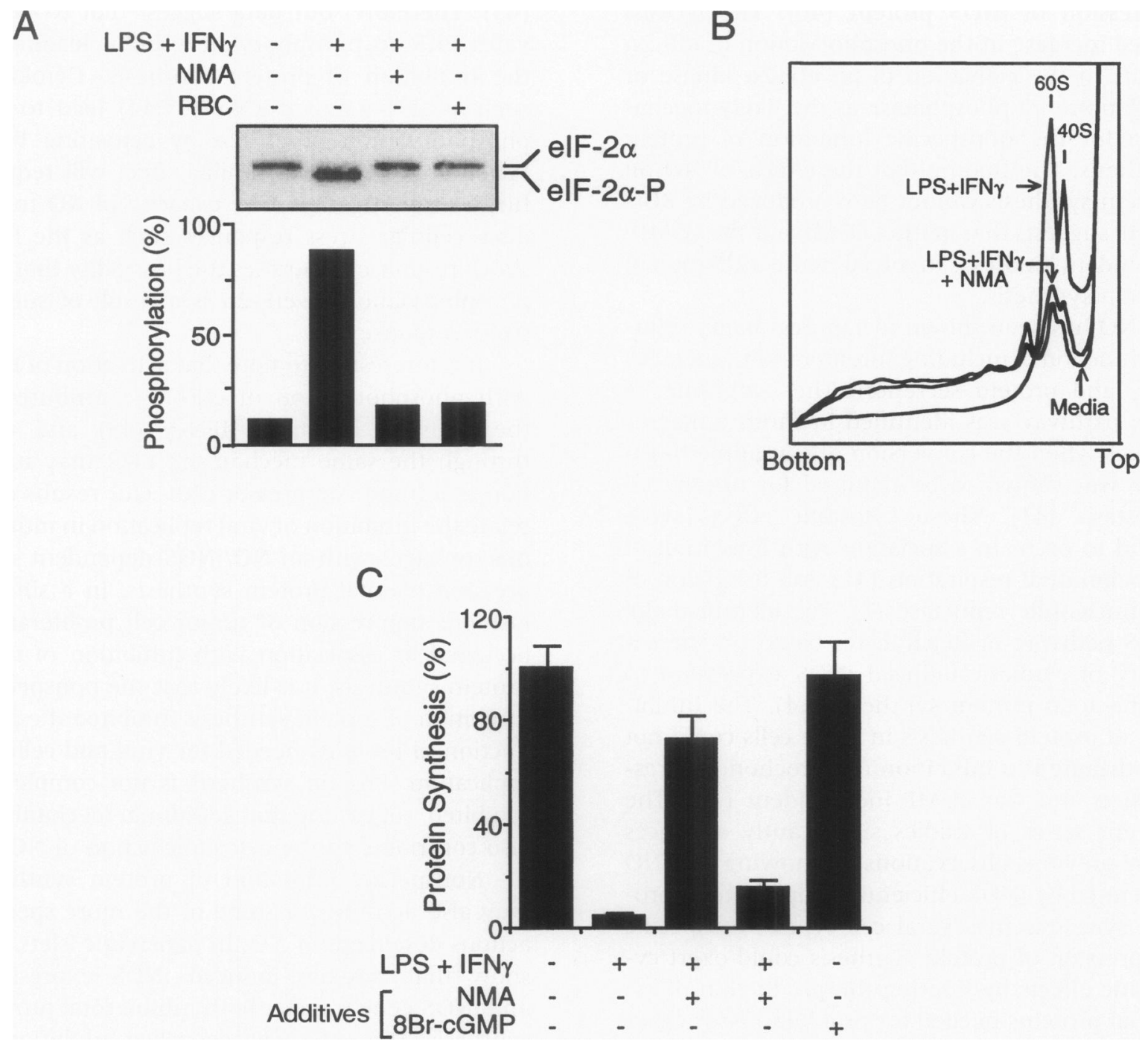

FIG. 6. NO inhibits ribosome complex formation through phosphorylation of eIF-2 $\alpha$. (A) RAW264.7 cells were stimulated with LPS + IFN- $\gamma$ for $14 \mathrm{hr}$. Cells were isolated and phosphorylation of eIF- $2 \alpha$ was analyzed after VIEF and immunoblotting with a monoclonal antibody to eIF- $2 \alpha$. (B) Ribosome profiles were determined by isolation of the cytosolic

and the failure to form the $80 \mathrm{~S}$ ribosomal complex, which is required for protein synthesis. NO is known to stimulate cGMP synthesis and thereby activate cGMP-dependent kinases (PKG); however, the addition of the cGMP analogue 8Br-cGMP to RAW264.7 cells did not inhibit protein synthesis (Fig. 6C).

\section{Discussion}

Although we originally described the capacity of NO to suppress protein synthesis in hepatocytes fraction of RAW264.7 treated with LPS + IFN- $\gamma$ for $24 \mathrm{hr}$, sucrose gradient centrifugation, and continuous measurement at an optical density of $280 \mathrm{~nm}$. (C) Cells were treated with LPS + IFN- $\gamma$ for $12 \mathrm{hr}$ and then labeled with ${ }^{35} \mathrm{~S}$-methionine for $2 \mathrm{hr}$ in the presence or absence of $400 \mu \mathrm{M} 8 \mathrm{Br}$-cGMP. Data are expressed as mean $\pm \mathrm{SD} ; n \geq 3$.

$(14,15)$, the uniformity of this observation to other cell types, as well its relationship to other established actions of induced NO and the mechanism of the inhibition, have remained unknown. We show here that NO donors and iNOS expression result in suppressed protein synthesis in several cell lines as well as primary cells and tissues. Our correlative studies suggest that nonspecific inhibition of protein synthesis contributes to several well-described actions of NO, including inhibition of cell proliferation (17), suppression of vaccinia virus replication (18), inhibition of islet protein secretion $(20,36)$, and 
expression of iNOS protein (40). The NO-induced increase in the phosphorylation of eIF- $2 \alpha$ points to the activation of an eIF- $2 \alpha$ kinase or inhibition of a phosphatase as the likely mechanism for the nonspecific inhibition of protein synthesis. The finding that the effects of NO on protein synthesis cannot be reproduced by $8 \mathrm{Br}$ cGMP suggests that neither CGMP nor the CGMPdependent kinases is involved in the inhibition of protein synthesis.

NO has been shown to suppress many cellular functions, including proliferation, metabolism, and protein secretion. The L-arginine $\rightarrow$ NOx pathway was identified in murine macrophages when the conversion of $\mathrm{L}$-arginine to nitrate was shown to be required for tumor cell cytostasis (41). These cytostatic effects were found to occur in association with inhibition of mitochondrial respiration (42) and inhibition of ribonucleotide reductase (7). We identified the iNOS pathway in hepatocytes based on the capacity of cytokine-induced iNOS expression to inhibit total protein synthesis (14). The inhibition of protein synthesis in these cells could not be attributed to inhibition of mitochondrial respiration and was cGMP independent (16). The current series of studies significantly advances these previous observations by showing that NO generated by iNOS efficiently suppress total protein synthesis in several cell types. Nonspecific suppression of protein synthesis could exert cytostatic effects by limiting the production of essential proteins needed for proliferation or other key cellular functions. Down-regulation of protein synthesis would have an even more profound influence on cellular events, such as intracellular microbial proliferation, that are dependent on rapid production of new proteins.

The uniformity of the response of cells for the inhibition of protein synthesis implicated a mechanism involving a control point in protein synthesis common to all cells. Phosphorylation of the $\alpha$ subunit of protein synthesis initiation factor eIF-2 is one of the best characterized translational control mechanisms. The phosphorylation of eIF- $2 \alpha$ on serine 51 prevents translation by impairing the eIF-2B-catalyzed guanine nucleotide exchange of eIF-2.GDP for GTP.eIF-2 required for the binding of the eIF-2/GTP/methionyl/tRNAi complex to the $43 \mathrm{~S}$ ribosomal subunit (24). Both PKR and HRI kinases have been shown to phosphorylate eIF- $2 \alpha$ in mammalian cells; however, PKR has a ubiquitous distribution whereas HRI is thought to be erythroid specific
(43). Therefore, our data suggest that NO activates PKR to phosphorylate eIF- $2 \alpha$, leading to the inhibition of protein synthesis. Cytokines such as IFN- $\gamma$ and dsRNA $(35,44)$ lead to the phosphorylation of eIF- $2 \alpha$ by activating PKR. Whether NO exerts a similar effect will require further investigation. The capacity of NO to induce cellular stress responses such as the heat shock response (12) raises the possibility that the phosphorylation of eIF- $2 \alpha$ is a result of such a stress response.

It is interesting to note that activation of PKR with phosphorylation of eIF- $2 \alpha$ contributes to the antiviral effects of IFN- $\gamma$ (35) and that through the same mechanism, PKR may function as a tumor suppressor (26). Our results correlate the inhibition of viral replication in murine macrophages with an NO/iNOS-dependent suppression of total protein synthesis. In a similar fashion, suppression of tumor cell proliferation occurred in association with inhibition of total protein synthesis. It is likely that the nonspecific inhibition of protein synthesis inhibited the production of proteins needed for viral and cellular replication. Protein synthesis is not completely inhibited, suggesting that additional mechanisms also contribute to the cytostatic action of NO.

Nonspecific inhibition of protein synthesis may also account for some of the more specific actions described for NO. In pancreatic islets, we show that cytokine-induced iNOS expression and iNOS gene transfer both inhibit total protein synthesis. Thus, the well-described inhibition of insulin production by islets following cytokineinduced iNOS expression could occur either totally or in part due to nonspecific inhibition of protein synthesis. This relationship is more specifically borne out in RAW264.7 cells where the inhibition of total protein synthesis is paralleled by the reduction in iNOS protein synthesis. This could represent a feedback mechanism to downregulate iNOS expression in conditions of excessive oxidative or nitrosative stresses, thereby turning off further NO production. More likely is the possibility that the inhibition of total protein synthesis in this setting is a stress response intended to transiently shut down nonessential functions to conserve cell resources during recovery. Prolonged inhibition of total protein synthesis, however, could lead to loss of cell viability. Taken together, our observations add to the growing list of NO targets, a key pathway in the control of protein synthesis. 


\section{Acknowledgments}

This work was supported by NIH grants R01GM-44100, R01-GM-37753, R29-HL-57854, R01-DK-16272 and Korean Science and Engineering Foundation Grant \#981-0714-100-2.

\section{References}

1. Billiar TR. (1995) Nitric oxide: Novel biology with clinical relevance. Ann. Surg. 221: 339-349.

2. Nathan C, Xie QW. (1994) Nitric oxide synthases: Roles, tolls, and controls. Cell 78: 915-918.

3. Nathan C. (1992) Nitric oxide as a secretory product of mammalian cells. FASEB J. 6: 3051-3064.

4. Farias-Eisner R, Sherman MP, Aeberhard E, Chaudhuri G. (1994) Nitric oxide is an important mediator for tumoricidal activity in vivo. Proc. Natl. Acad. Sci. USA 91: 9407-9411.

5. Son K, Kim YM. (1995) In vivo cisplatin-exposed macrophages increase immunostimulant-induced nitric oxide synthesis for tumor cell killing. Cancer Res. 55: 5524-5527.

6. Kim YM, Hong SJ, Billiar TR, Simmons RL. (1996) Counterprotective effect of erythrocytes in experimental bacterial peritonitis is due to scavenging of nitric oxide and reactive oxygen intermediates. Infect. Immun. 64: 3074-3080.

7. Lepoivre $M$, Flaman JM, Bobe P, Lemaire G, Henry Y. (1994) Quenching of the tyrosyl free radical of ribonucleotide reductase by nitric oxide. Relationship to cytostasis induced in tumor cells by cytotoxic macrophages. J. Biol. Chem. 269: 21891-21897.

8. Drapier JC, Hibbs JB Jr. (1986) Murine cytotoxic activated macrophages inhibit aconitase in tumor cells. Inhibition involves the iron-sulfur prosthetic group and is reversible. J. Clin. Invest. 78: 790-797.

9. Drapier JC, Hibbs JB Jr. (1988) Differentiation of murine macrophages to express nonspecific cytotoxicity for tumor cells results in L-arginine-dependent inhibition of mitochondrial iron-sulfur enzymes in the macrophage effector cells. J. Immunol. 140: 2829-2838.

10. Beckman JS, Beckman TW, Chen J, Marshall PA, Freeman BA. (1990) Apparent hydroxyl radical production by peroxynitrite: implications for endothelial injury from nitric oxide and super-oxide. Proc. Natl. Acad. Sci. USA 87: 1620-1624.

11. Kim YM, Bergonia HA, Muller C, Pitt BR, Watkins WD, Lancaster JR Jr. (1995) Loss and degradation of enzyme-bound heme induced by cellular nitric oxide synthesis. J. Biol. Chem. 270: 5710-5713.

12. Kim YM, de Vera JE, Watkins SC, Billiar TR. (1997) Nitric oxide protects cultured rat hepatocytes from tumor necrosis factor-alpha-induced apoptosis by inducing heat shock protein 70 expression. J. Biol. Chem. 272: 1402-1411.

13. Kim YM, Bergonia HA, Muller C, Pitt BR, Watkins
WD, Lancaster JR Jr. (1995) Nitric oxide and intracellular heme. Adv. Pharmacol. 34: 277-291.

14. Curran RD, Billiar TR, Stuehr DJ, Hofmann K, Simmons RL. (1989) Hepatocytes produce nitrogen oxides from $\mathrm{L}$-arginine in response to inflammatory products of Kupffer cells. J. Exp. Med. 170: 1769-1774.

15. Billiar TR, Curran RD, Stuehr DJ, West MA, Bentz BG, Simmons RL. (1989) An L-arginine dependent mechanism mediates Kupffer cell influences on hepatocyte protein synthesis in vitro. J. Exp. Med. 169: 1467-1472.

16. Curran RD, Ferrari FK, Kispert PH, et al. (1991) Nitric oxide and nitric oxide-generating compounds inhibit hepatocyte protein synthesis. FASEB J. 5: 2085-2092.

17. Jenkins DC, Charles IG, Thomsen LL, et al. (1995) Roles of nitric oxide in tumor growth. Proc. Natl. Acad. Sci. USA 92: 4392-4396.

18. Karupiah G, Xie QW, Buller RM, Nathan C, Duarte C, MacMicking JD. (1993) Inhibition of viral replication by interferon-gamma-induced nitric oxide synthase. Science 261: 1445-1448.

19. Lowenstein CJ, Hill SL, Lafond-Walker A, et al. (1996) Nitric oxide inhibits viral replication in murine myocarditis. J. Clin. Invest. 97: 1837-1843.

20. Corbett JA, Lancaster JR Jr, Sweetland MA, McDaniel ML. (1991) Interleukin-1-beta-induced formation of EPR-detectable iron-nitrosyl complexes in islets of Langerhans. Role of nitric oxide in interleukin-1-beta-induced inhibition of insulin secretion. J. Biol. Chem. 266: 21351-21354.

21. De Benedetti A, Baglioni C. (1983) Phosphorylation of initiation factor eIF- $2 \alpha$, binding of mRNA to $48 \mathrm{~S}$ complexes, and its reutilization in initiation of protein synthesis. J. Biol. Chem. 258: 1455614562.

22. Chen JJ, Throop MS, Gehrke L, et al. (1991) Cloning of the cDNA of the heme-regulated eukaryotic initiation factor 2 alpha (eIF-2 $\alpha$ ) kinase of rabbit reticulocytes: homology to yeast GCN2 protein kinase and human double-stranded-RNA-dependent eIF- $2 \alpha$ kinase. Proc. Natl. Acad. Sci. USA 88: 7729-7733.

23. Crosby JS, Lee K, London IM, Chen JJ. (1994) Erythroid expression of the heme-regulated eIF-2 alpha kinase. Mol. Cell. Biol. 14: 3906-3914.

24. Samuel CE. (1993) The eIF-2 $\alpha$ protein kinase, regulators of translation in eukaryotes from yeasts to humans. J. Biol. Chem. 268: 7603-7606.

25. Meurs EF, Watanabe Y, Kadereit S, et al. (1992) Constitutive expression of human doublestranded RNA-activated p68 kinase in murine cells mediates phosphorylation of eukaryotic initiation factor 2 and partial resistance to encephalomyocarditis virus growth. J. Virol. 66: 58045814.

26. Meurs EF, Galabru J, Barber GN, Katze MG, Hovanessian AG. (1993) Tumor suppressor function of the interferon-induced double-stranded 
RNA-activated protein kinase. Proc. Natl. Acad. Sci. USA 90: 232-236.

27. Hinnebusch AG. (1994) The eIF-2 alpha kinases: Regulators of protein synthesis in starvation and stress. Semin. Cell Biol. 5: 417-426.

28. Saville B. (1958) A scheme for the colorimetric determination of microgram amounts of thiol. $A n$ alyst 83: 670-672.

29. Tzeng E, Kim YM, Pitt BR, Lizonova A, Kovesdi I, Billiar TR. (1997) Adenoviral transfer of the inducible nitric oxide synthase gene blocks endothelial cell apoptosis. Surgery 122: 255-263.

30. Kwon G, Bohrer A, Han X, et al. (1996) Characterization of the sphingomyelin content of isolated pancreatic islets. Evaluation of the role of sphingomyelin hydrolysis in the action of interleukin-1 to induce islet overproduction of nitric oxide. Biochim. Biophys. Acta 1300: 63-72.

31. Kim YM, Son K. (1996) A nitric oxide production bioassay for interferon-gamma. J. Immunol. Methods 198: 203-209.

32. Chen W, Drillien R, Spehner D, Buller RML. (1992) Restricted replication of Ectromelia virus in cell culture correlates with mutations in virusencoded host range gene. Virology 187: 433-442.

33. Maurides PA, Akkaraju GR, Jagus R. (1989) Evaluation of protein phosphorylation state by a combination of vertical slab gel isoelectric focusing and immunoblotting. Anal. Biochem. 183: 144-151.

34. Kim YM, Lancaster JR Jr. (1993) Tetrahydrobiopterin-dependent nitrite oxidation to nitrate in isolated rat hepatocytes. FEBS Lett. 332: 255-259.

35. Der SD, Lau AS. (1995) Involvement of the double-stranded-RNA-dependent kinase PKR in interferon expression and interferon-mediated antiviral activity. Proc. Natl. Acad. Sci. USA 92: 8841-8845.

36. Corbett JA, Sweetland MA, Wang JL, Lancaster JR Jr, McDaniel ML. (1993) Nitric oxide mediates cytokine-induced inhibition of insulin secretion by human islets of Langerhans. Proc. Natl. Acad. Sci. USA 90: 1731-1735.
37. Stadler J, Bergonia HA, Di Silvio M, et al. (1993) Nonheme iron-nitrosyl complex formation in rat hepatocytes: detection by electron paramagnetic resonance spectroscopy. Arch. Biochem. Biophys. 302: 4-11.

38. Yang JM, London IM, Chen JJ. (1992) Effects of hemin and porphyrin compounds on intersubunit disulfide formation in heme-regulated eIF-2 alpha kinase and the regulation of protein synthesis in reticulocyte lysates. J. Biol Chem. 267: 2051920524.

39. Ramaiah KV, Dhindsa RS, Chen JJ, London IM, Levein D. (1992) Recycling and phosphorylation of eukaryotic initiation factor 2 on 605 subunits of $80 S$ initiation complexes and polysomes. Proc. Natl. Acad. Sci. USA 89: 12063-12067.

40. Sheffler LA, Wink DA, Melillo G, Cox GW. (1995) Exogenous nitric oxide regulates IFN-gamma plus lipopolysaccharide-induced nitric oxide synthase expression in mouse macrophages. J. Immunol. 155: $886-894$.

41. Hibbs JB Jr, Taintor RR, Vavrin Z. (1987) Macrophage cytotoxicity: role for L-arginine deiminase and imino nitrogen oxidation to nitrite. Science 235: 473-476.

42. Drapier JC, Hibbs JB Jr. (1988) Differentiation of murine macrophages to express nonspecific cytotoxicity for tumor cells results in L-arginine-dependent inhibition of mitochondrial iron-sulfur enzymes in the macrophage effector cells. J. Immunol. 140: 2829-2838.

43. Petryshyn R, Trachsel H, London IM. (1979) Regulation of protein synthesis in reticulocyte lysates: Immune serum inhibits heme-regulated protein kinase activity and differentiates heme-regulated protein kinase from double-stranded RNA-induced protein kinase. Proc. Natl. Acad. Sci. USA 76: 1575-1579.

44. Wu S, Kaufman RJ. (1997) A model for the double-stranded RNA (dsRNA)-dependent dimerization and activation of the dsRNA-activated protein kinase PKR. J. Biol. Chem. 272: 1291-1296. 